\title{
ANALISANDO OS PRINCÍPIOS E GARANTIAS DE DIREITOS HUMANOS APLICADOS À MIGRAÇÃO
}

\begin{abstract}
RESUMO
Este trabalho buscou analisar os contornos e racionalidades dos Direitos Humanos aplicados à migração, do ponto de vista de Pareceres Consultivos emitidos pela Corte Interamericana de Direitos Humanos sobre condição jurídica e os direitos dos migrantes indocumentados e da infância migrante na América Latina. Analisou-se, sobretudo, os direitos e garantias elencados nos documentos expedidos pela Corte Interamericana, consoante as exigências de proteção dos migrantes em situação de vulnerabilidade no âmbito migratório. Concluiu-se que os Pareceres Consultivos objeto dos estudos inauguram uma nova perspectiva no tratamento jurídico a ser conferido a todas as pessoas no contexto da migração.
\end{abstract}

Palavras-chave: Pareceres Consultivos; Direitos Humanos; Migração.

${ }^{1}$ Docente permanente do Programa de Pós-Graduação Stricto Sensu em Ciências Ambientais da Universidade Brasil - Campus de Fernandópolis. Professora de Direito Constitucional na Universidade do Estado de Minas Gerais - UEMG. Possui pós-doutorado em Direito e Saúde, pela Universidade de Messina, Itália, doutorado em Sistema Constitucional de Garantias de Direito pelo Instituto Toledo de Ensino, graduação em Direito - Faculdades Integradas Riopretense, mestrado em Direito pela Universidade de Ribeirão Preto e doutorado em Derecho Empresarial pela Universidade de Extremadura. Participa dos grupos de pesquisa do CNPQ Ciências Ambientais e Saúde e Sustentabilidade Integrada dos Municípios da UnivBrasil e Cultura, Direito \& Sociedade da Universidade do Estado de Minas Gerais (UEMG). Tem experiência na área de Direito, com ênfase em Direito Constitucional, ambiental, função social do direito, direitos coletivos, federalismo, pacto federativo e inclusão social. Contato: cristina.castro@uemg.br. http://lattes.cnpq.br/6448783790311393. 


\begin{abstract}
This study aimed to analyze the contours and rationales of Human Rights applied to the migration from the point of view of Advisory Opinions issued by the Inter-American Court of Human Rights on legal status and rights of undocumented migrants and migrant children in Latin America. Analyzed above all the rights and guarantees listed in the documents issued by the Inter-American Court, depending on the protection needs of migrants in vulnerable situations in the migration sphere. It was concluded that the Advisory Opinions studies of object inaugurate a new perspective in the legal treatment to all persons in migration.
\end{abstract}

Keywords: Advisory Opinions; Human Rights; Migration.

\title{
1 INTRODUÇÃO
}

O tema central da pesquisa situa-se na perspectiva de verificar quais são os direitos humanos aplicados na migração.

Já o problema levantado seria o de compreender se os Pareces Consultivos emitidos pela Corte Interamericana de Direitos Humanos sobre condição jurídica e os direitos dos migrantes indocumentados e da infância migrante na América Latina trariam uma nova perspectiva em relação aos direitos em questão.

O objetivo do trabalho é iniciar um debate sobre os direitos dos migrantes, de forma que seja possível verificar qual o posicionamento recente da Corte Interamericana de Direitos Humanos sobre o tema. Quanto aos objetivos específicos são debater sobre o papel da Corte Interamericana, política migratória e expansão dos direitos humanos.

A justificativa da pesquisa encontra-se na expansão dos problemas relacionados ao tema nos últimos anos, em especial com o aumento da migração por causas naturais e políticas.

Quanto ao método, a pesquisa valeu-se de uma análise bibliográfica e do método hipotético-dedutivo.

\section{DA PROTEÇÃO DO MIGRANTE NA ESFERA INTERNACIONAL}

No atual cenário da globalização, a discussão sobre os direitos humanos aplicados a migração encontra-se na pauta da ordem do dia para debate relativamente a proteção global dos estrangeiros diante das políticas estatais estabelecidas no campo migratório. 
De acordo com a evolução jurídica universal contra violações aos direitos humanos, a proteção que se estabeleceu no âmbito internacional ganhou destaque a partir das lutas históricas e da construção doutrinária que, de início, negava ao indivíduo a categoria de sujeito de direito.

Com o passar dos anos, começou-se a admitir, na esfera internacional, tratamento idêntico dado às pessoas nacionais, elevando o ser humano a categoria de sujeito de direito sem qualquer limitação de critério territorial.

André de Carvalho Ramos (2001, p. 44-45) bem explica que a definição de direito internacional de direitos humanos dá-se como o "conjunto de normas jurídicas internacionais, reconhecidas universalmente, que obrigam os Estados a respeitar e garantir certos direitos a todos a todos os seres humanos sob sua jurisdição, sejam nacionais ou não".

O ápice da consolidação do direito internacional dos direitos humanos se deu efetivamente com a Declaração Universal dos Direitos do Homem no ano de 1948, surgindo como resposta aos reflexos deixados pela Segunda Guerra Mundial, na qual a violação extrema dos direitos humanos se fazia presente naquele momento, tornando-se inegável sua aplicação em defesa dos migrantes na condição de vulneráveis.

No entanto, no campo da migração, essa proteção dos direitos universais deixa a desejar a partir do momento no qual se discute sobre quem é o nacional e o estrangeiro, predominando, constantemente, violência, hostilidade e abusos aos migrantes pelas manifestações contrárias aos direitos humanitários, conforme salienta Maritza Natalia Ferretti Cisneros Farena (2012, p. 59):

No que concerne aos migrantes, no entanto, a situação é muito difícil, pois se esquece que, como seres humanos, também são titulares da proteção dos direitos humanos. Esta normativa deveria bastar para garantir a proteção de todos, por sermos pessoas e não porque somos nacionais de um determinado país, ou porque nos encontramos em certo território. As pessoas não deveriam perder nenhum dos seus direitos básicos pelo mero fato de migrar ou mudar o lugar de sua residência. Sem embargo, testemunhamos violências, abusos e hostilidades contra os migrantes no mundo inteiro, inclusive muitos são tolhidos até entrar no Estado de destino.

Entretanto, historicamente, Francisco de Vitória já defendeu no passado a teoria do "jus communicationis", sustentando que deveria haver, no plano internacional, o direito a emigração e imigração de pessoas, 
ou seja, a livre circulação mundial, salientando que a comunicação entre os povos no contexto da migração seria totalmente possível, conforme pontua Luís Renato Vedovato (2013, p. 59):

Em sentido oposto à liberdade do Estado de decidir sobre o in-
gresso de estrangeiros, posiciona-se Vitória, responsável pela teo-
ria segundo a qual todos podem circular livremente pelo mundo.
O doutrinador espanhol foi um defensor da liberdade dos mares,
fazendo nascer o jus communicationis, que seria aplicável ao di-
reito de comércio e à liberdade de navegação.

A teoria vitoriana permitia, assim, que não houvesse o impedimento de circulação, em especial dos espanhóis conquistadores do Novo Mundo, de viajar para adentrar os espaços em que habitavam os índios. Referida teoria teria fundamento em uma normatividade natural, podendo ser fundamento tanto divino quanto humano, tendo em vista que o direito natural e o divino preconizavam que a comunicação, entendida como circulação, seria totalmente possível.

Apesar disso, o que se tem visto atualmente é a atuação do Estado no sentido de restringir cada vez mais os direitos da pessoa humana no contexto da migração, tendo em vista que a circulação de pessoas no âmbito internacional envolve fatores políticos e sentimentos de xenofobia, especialmente pela comunidade europeia, que alega como justificativa a segurança nacional para restringir a entrada de estrangeiros.

Essa justificativa apontada pelos Estados para restrição da entrada de estrangeiros apresenta elementos implícitos. Um deles é o fator econômico pela qual atualmente passam os países da Europa, tendo em vista que, com o aumento da União Europeia, ou seja, entrada de países na comunidade, aliado ao fato da recessão na produção das grandes industrias, faz com que europeus menos qualificados aceitem empregos que, em tese, seriam feitos pelos estrangeiros sem qualificação que adentrassem no país.

Diante disso, além da divergência entre o respeito aos direitos humanos e as políticas migratórias estabelecidas pelos Estados, o direito internacional impôs como condição primordial uma soberania flexibilizada que se utilize das regras da ponderação a fim de conciliar o respeito à dignidade da pessoa humana e o direito dos Estados de estabelecerem suas políticas no campo da migração, sempre com a finalidade de evitar o arbítrio dos países de forma ilimitada, na medida em que os direitos do homem deveriam estar sempre acima dos direitos do Estado. 
Nesse sentido, a Carta da Organização das Nações Unidas (ONU) declarou em seu art. $2^{\circ}(7)$ que "O respeito aos direitos humanos não é assunto de interesse exclusivamente interno de um Estado, mas sim de toda a comunidade mundial", demonstrando que os mecanismos internacionais devem estar presentes nas atividades internas dos Estados.

Acerca do assunto, dispõe Antonio Augusto Cançado Trindade (1991, p. 3-4) que:

\begin{abstract}
O desenvolvimento histórico da proteção internacional dos direitos humanos gradualmente superou barreiras do passado: compreendeu-se aos poucos, que a proteção dos direitos básicos da pessoa humana não se esgota, como não poderia se esgotar, na atuação do Estado, na pretensa e indemonstrável competência nacional exclusiva. Esta última afigura-se como um reflexo, manifestação ou particularização, da própria noção de soberania, inteiramente adequada ao plano das relações internacionais, porquanto originalmente concebida, tendo em mente o Estado in abstracto (e não em suas relações com outros Estados), e como expressão de um poder interno, de uma supremacia própria de um ordenamento de subordinação, claramente distinto do ordenamento internacional, de coordenação e cooperação, em que todos os Estados são, ademais de independentes, juridicamente iguais.
\end{abstract}

Assim, a liberdade dos Estados de disporem sobre suas próprias leis internas no campo da migração também sofrem reflexos diante dos tratados internacionais de direitos humanos, na medida em que o pressuposto de sua aplicação reclama a proteção da pessoa humana, de acordo com o postulado do direito internacional, tendo em vista que o Estado não poderá alegar como justificativa para não aplicação dos tratados a legislação interna de seus países como normas constitucionais.

Com isso, o direito internacional dos direitos humanos, com a finalidade de evitar o livre arbítrio das soberanias estatais e a exclusão dos indivíduos, além do desrespeito aos direitos humanos, estabeleceu no âmbito internacional princípios e mecanismos inafastáveis para proteção dos migrantes, uma vez que tais direitos se caracterizam de forma universal e independem de nacionalidade ou critérios territoriais.

A proteção do migrante ganha destaque com a Convenção sobre os Direitos dos Trabalhadores Migrantes e suas famílias no ano de 1.990, uma vez que a preocupação acerca do assunto surge a partir do crescente desrespeito à dignidade da pessoa humana, na medida em que a exploração laboral e a ausência de legislação trabalhista e assistencial tornam-se obstáculos para proteção do migrante. 
A ideia de assegurar uma nova ordem jurídica internacional, fundada na afirmação do direito internacional dos direitos humanos, foi a de concretizar a paz mundial entre todos os povos, no sentido de que o surgimento de instituições e instrumentos jurídicos internacionais tiveram por objetivo estabelecer o equilíbrio entre a proteção dos direitos humanos e as políticas estatais no campo migratório.

Atualmente são inúmeros os documentos que garantem a proteção dos direitos humanos dos migrantes. A Carta das Nações Unidas e Convenção Interamericana dos Direitos Humanos são exemplos da proteção do estrangeiro em nível universal.

A Carta das Nações Unidas prevê em seu conteúdo os princípios da igualdade e o da não discriminação dos direitos da pessoa humana, estabelecendo que todos devem desfrutar dos mesmos direitos sem discriminação.

Maritza Natalia Ferretti Cisneros Farena (2012, p. 69) expõe que:

Os princípios da igualdade e da universalidade dos direitos humanos impedem qualquer tipo de discriminação no concernente aos direitos fundamentais dos migrantes, pois todos devem gozar de iguais direitos, independentemente da nacionalidade, raça, etnia, origem ou qualquer outra circunstância. Este princípio também fundamenta ações afirmativas que o façam valer, de forma a tornar iguais em direitos aqueles pela sua vulnerabilidade sejam desiguais.

Há também a Carta Internacional dos Direitos Humanos da ONU, formada pela reunião da Declaração Universal dos Direitos do Homem e por dois Pactos adotados pela Assembleia Geral da ONU em 1966: Pacto Internacional de Direitos Civis e Políticos e Pacto Internacional dos Direitos Econômicos, Sociais e Culturais.

Esses documentos consagram, além do princípio da igualdade e da não discriminação, o princípio da universalidade, afirmando que todas as pessoas possuem direitos independentemente de sua nacionalidade, conforme bem explica Guido Fernando Silva Soares (2004, p. 72):

Embora os direitos humanos, por sua própria natureza, não possam comportar uma distinção entre indivíduos nacionais e estrangeiros, foram, nos primórdios da história de seu desenvolvimento, na forma de normas do jus scriptum, direitos expressos num sistema jurídico nacional fechado, dentro do qual seria possível comportar uma discriminação entre os nacionais e estrangeiros. Mas, na medida em que a pessoa humana tem seus direitos defini- 
dos em normas internacionais, que desbordam os limites dos ordenamentos jurídicos nacionais, aquela discriminação perde sua razão de ser, e, bem ao contrário, torna-se odiosa.

À medida que os direitos humanos são definidos em relação a qualquer indivíduo, onde quer que se encontre, no tempo e no espaço, e que são direitos exigíveis de qualquer Estado, fazer discriminação em razão de origem nacional passa a ser a negação da universalidade da pessoa humana.

Além disso, o Pacto Internacional dos Direitos Civis e Políticos estabelece, dentre os princípios acima, direitos como liberdade de circulação, de participação na vida pública e, principalmente, proteção dos direitos da minoria, ressalvando ainda o direito à vida e repressão contra qualquer espécie de tortura.

Já o Pacto Internacional dos Direitos Econômicos, Sociais e Culturais preconiza o direito ao trabalho e a seguridade social, na medida em que estão englobados a educação e os benefícios da liberdade cultural além dos limites territoriais.

Importante também ressaltar a relevante contribuição trazida pelo Parecer OC 18/03, solicitada pelo México no ano de 2002, que trata da proteção dos migrantes indocumentados, da qual sua análise merece destaque.

\section{DA ANÁLISE DO PARECER CONSULTIVO OC-18/03 DE 17 DE SETEMBRO DE 2003, SOLICITADO PELOS ESTADOS UNIDOS MEXICANOS - A CONDIÇÃO JURÍDICA E OS DIREITOS DOS MIGRANTES INDOCUMENTADOS}

Em 10 de maio de 2002, os Estados Unidos Mexicanos, solicitou, com fundamento no artigo 64.1 da Convenção Americana sobre Direitos Humanos (doravante denominada "a Convenção Americana", "a Convenção" ou "o Pacto de San José"), à Corte Interamericana de Direitos Humanos um pedido de Parecer Consultivo relativamente sobre a privação dos direitos trabalhistas dos migrantes e sua compatibilidade com a obrigação dos Estados americanos de garantir os princípios de igualdade jurídica, não discriminação e proteção igualitária previstos em instrumentos internacionais de proteção aos direitos humanos, ressaltando a subordinação ou condicionamento da observância das obrigações im- 
postas pelo Direito Internacional dos Direitos Humanos, conforme razões expostas pelo Estado Mexicano:

\begin{abstract}
Os trabalhadores migrantes, bem como o restante das pessoas, devem ter garantido o desfrute e exercício dos direitos humanos nos Estados onde residem. Entretanto, sua vulnerabilidade os torna alvo fácil de violações a seus direitos humanos, em especial baseadas em critérios de discriminação e, em consequência, coloca-os em uma situação de desigualdade perante a lei quanto [a]o desfrute e exercício efetivos destes direitos. [...] No contexto já descrito, preocupa-lhe profundamente o Governo do México a incompatibilidade de interpretações, práticas e expedição de leis por parte de alguns Estados da região, com o sistema de direitos humanos da OEA. O Governo do México considera que tais interpretações, práticas ou leis implicam negar, entre outros, direitos trabalhistas com base em critérios discriminatórios fundamentados na condição migratória dos trabalhadores indocumentados. $\mathrm{O}$ anterior poderia alentar os empregadores a utilizar essas leis ou interpretações para justificar a perda progressiva de outros direitos trabalhistas. Por exemplo: pagamento de horas extras, antiguidade no emprego, salários atrasados, licença maternidade, abusando assim da condição de vulnerabilidade em que se encontram os trabalhadores migrantes indocumentados. Nesse contexto, as violações aos instrumentos internacionais que protegem os direitos humanos dos trabalhadores migrantes na região constituem uma ameaça real para a vigência dos direitos protegidos por tais instrumentos. ${ }^{2}$
\end{abstract}

Nesse sentido, o Parecer OC 18/03 teve por finalidade o reconhecimento pela comunidade internacional da necessidade de proteção especial dos direitos humanos dos migrantes em situação de vulnerabilidade, tendo em vista que países da região negam a aplicação dos direitos humanos e trabalhistas, com fundamento em critérios discriminatórios por tratar-se de trabalhadores indocumentados.

No entanto, a Corte Interamericana dos Direitos Humanos expressou manifestação no sentido de que os países devem assegurar o respeito aos direitos humanos, bem como o princípio da não discriminação, constituindo imperativo constitucional aplicável a todas as nações, independentes de serem partes ou não de tratados internacionais, conforme se verifica do parecer OC 18/03:

A Corte, nesta oportunidade, precisou o alcance das obrigações dos Estados membros da Organização dos Estados Americanos, de respeitar e garantir os direitos trabalhistas dos trabalhadores migrantes indocumentados, independentemente de sua nacionali-

\footnotetext{
${ }^{2}$ Trecho Extraído do Parecer Consultivo OC-18/03 de 17 de Setembro de 2003, solicitado pelos Estados Unidos Mexicanos - A Condição Jurídica e os Direitos Dos Migrantes Indocumentados.
} 
dade, ao estabelecer que o princípio de igualdade e não discriminação, que é fundamental para a proteção destes direitos, pertence ao jus cogens. ${ }^{3}$

Esta precisão conduz a Corte a declarar, igualmente, que os Estados, sejam ou não partes de um determinado tratado internacional, estão obrigados a proteger os direitos de igualdade e não discriminação e que essa obrigação tem efeitos erga omnes, não apenas em relação aos Estados, mas também frente a terceiros e particulares. Os Estados devem, portanto, respeitar e garantir os direitos trabalhistas dos trabalhadores, seja qual for seu status migratório, e, ao mesmo tempo, devem impedir que empregadores privados violem os direitos dos trabalhadores migrantes indocumentados ou que a relação de trabalho viole os padrões mínimos internacionais. Para que seja efetiva a tutela dos direitos trabalhistas dos imigrantes indocumentados é necessário que se garanta a estes o acesso à justiça e o devido processo legal. ${ }^{4}$

\section{Assegurou-se também a todos os estrangeiros em situação irre- gular a ampla defesa e do devido processo legal, uma vez que o migrante tem o direito de se defender, mediante processo, nos casos que envolvam violações aos direitos humanos, expulsão, deportação ou até mesmo a detenção do migrante nos respectivos Estados. \\ Sobre o assunto, expressa o parecer:}

A proclamação de direitos sem a provisão de garantias para exercê-los fica no vazio. Converte-se em uma formulação estéril, que semeia expectativas e produz frustrações. Por isso é preciso estabelecer as garantias que permitam reivindicar o reconhecimento

\footnotetext{
${ }^{3}$ Afirmar que o princípio de igualdade e não discriminação pertence ao domínio do jus cogens, tem, segundo o Tribunal Europeu de Direitos Humanos vários efeitos jurídicos: o reconhecimento de que a norma é hierarquicamente superior a respeito de qualquer norma de direito internacional, excetuando outras normas de jus cogens; em caso de conflito, teria primazia a norma de jus cogens frente a qualquer outra norma de direito internacional, e seria nula ou careceria de efeitos jurídicos a disposição que contradiga a norma imperativa. (Tomado dos argumentos das Clínicas Jurídicas da Faculdade de Direito da Universidade San Francisco de Quito).

${ }^{4}$ No Parecer Consultivo OC-16/99 de $1^{\circ}$ de outubro de 1999, a Corte Interamericana de Direitos Humanos, afirmou que "para que exista "devido processo legal" é preciso que um acusado possa exercer seus direitos e defender seus interesses de forma efetiva e em condições de igualdade processual com outros acusados. Com efeito, é útil recordar que o processo é um meio para assegurar, na maior medida possível, a solução justa de uma controvérsia. A esse fim responde o conjunto de atos de diversas características geralmente reunidos sob o conceito do devido processo legal. O desenvolvimento histórico do processo, coerente com a proteção do indivíduo e a realização da justiça, trouxe consigo a incorporação de novos direitos processuais. São exemplo deste caráter evolutivo do processo os direitos a não se autoincriminar e a depor na presença de um advogado, que hoje em dia figuram na legislação e na jurisprudência dos sistemas jurídicos mais avançados. Desta forma, progressivamente, foi estabelecido o aparato das garantias judiciais recopiladas pelo artigo 14 do Pacto Internacional sobre Direitos Civis e Políticos, que podem e devem agregar-se, sob o mesmo conceito, de outras garantias apresentadas por diversos instrumentos do Direito Internacional".
} 
dos direitos, recuperá-los quando foram desconhecidos, restabelecê-los se foram violados e colocá-los em prática quando seu exercício tropeça em obstáculos indevidos. A isso atende o princípio de acesso igual e expresso à proteção jurisdicional efetiva, isto é, a possibilidade real de ter acesso à justiça através dos meios que o ordenamento interno proporciona a todas as pessoas, com a finalidade de alcançar uma solução justa à controvérsia que se suscitou. Em outros termos: acesso formal e material à justiça. A esse acesso serve o devido processo, amplamente examinado pela Corte Interamericana de Direitos Humanos no exercício de suas competências consultiva e contenciosa. A rigor, o devido processo é o meio consequente com o mais avançado conceito dos direitos humanos para assegurar a efetiva realização destes direitos: um método ou fator para a eficácia do direito em seu conjunto e dos direitos subjetivos em casos concretos. $\mathrm{O}$ devido processo, conceito dinâmico guiado e desenvolvido sob um modelo garantidor que serve aos interesses e direitos individuais e sociais, bem como ao supremo interesse da justiça, constitui um princípio orientador para a devida solução dos litígios e um direito primordial de todas as pessoas. Aplica-se à solução de controvérsias de qualquer natureza - entre elas, obviamente, as trabalhistas - e às petições e reivindicações que se apresentam perante quaisquer autoridades: judiciais ou administrativas. $\mathrm{O}$ devido processo, em seus elementos que interessam para o objeto do OC-18/2003, implica, por uma parte, a maior igualdade --equilíbrio, "igualdade de armas" - entre os litigantes, particularmente importante quando em um extremo da disputa se encontra o vulnerável trabalhador migrante e no outro o empregador dotado de direitos suficientes e eficientes, uma igualdade que apenas se consegue - na maioria dos casos, que refletem a verdadeira dimensão do problema coletivo - quando o poder público incorpora, através de leis e critérios de interpretação e aplicação, os elementos de compensação ou correção aos que antes me referi; e, além disso, o cumprimento claro e fluído do dever que tem o Estado de oferecer o serviço de justiça, sem distinção e, muito menos, discriminação, que implicaria, de entrada, a derrota do acusado débil. ${ }^{5}$

\section{A despeito disso, a Corte ainda menciona que não é considerada discriminatória a distinção entre migrantes regulares e irregulares, desde que tal distinção seja feita de forma razoável e proporcional, sem qual- quer violação aos direitos humanos, tendo em vista que a regularização no país não poderá ser utilizada como critério para aplicação dos princí- pios da igualdade e da não discriminação. \\ No que diz respeito aos trabalhadores imigrantes, a Corte res- saltou que a criação de vínculos de emprego em determinado trabalho acarreta em face do estrangeiro a aquisição dos direitos trabalhistas pre-}

\footnotetext{
${ }^{5}$ Trecho Extraído do Parecer Consultivo OC-18/03 de 17 de Setembro de 2003, solicitado pelos Estados Unidos Mexicanos - A Condição Jurídica e os Direitos Dos Migrantes Indocumentados.
} 
vistos na legislação do respectivo Estado, pois o respeito e garantia dos direitos trabalhistas devem ser aplicados de forma igualitária, sem qualquer espécie de discriminação, independentemente da nacionalidade do migrante.

Os direitos trabalhistas surgem necessariamente da condição de trabalhador, entendida em seu sentido mais amplo. Toda pessoa que irá realizar, realize ou tenha realizado uma atividade remunerada, adquire imediatamente a condição de trabalhador e, consequentemente, os direitos inerentes a esta condição. $\mathrm{O}$ direito do trabalho, seja regulamentado no âmbito nacional ou internacional, é um ordenamento tutelar dos trabalhadores, isto é, regulamenta os direitos e obrigações do empregado e do empregador, independentemente de qualquer outra consideração de caráter econômico ou social. Uma pessoa que ingressa a um Estado e estabelece relações trabalhistas, adquire seus direitos humanos trabalhistas nesse Estado de emprego, independentemente de sua situação migratória, visto que o respeito e garantia do desfrute e exercício destes direitos devem se realizar sem nenhuma discriminação. ${ }^{6}$

Consequentemente, o Estado tem a obrigação de respeitar e garantir os direitos humanos trabalhistas, sem qualquer espécie de discriminação nas relações de trabalho, respeitado, ainda, os padrões mínimos estabelecidos no âmbito internacional.

\section{Acerca do assunto, confira-se:}

Que o Estado tem a obrigação de respeitar e garantir os direitos humanos trabalhistas de todos os trabalhadores, independentemente de sua condição de nacionais ou estrangeiros, e não tolerar situações de discriminação em detrimento destes nas relações de trabalho que se estabeleçam entre particulares (empregadortrabalhador). O Estado não deve permitir que os empregadores privados violem os direitos dos trabalhadores, nem que a relação contratual viole os padrões mínimos internacionais. Que os trabalhadores, ao serem titulares dos direitos trabalhistas, devem contar com todos os meios adequados para exercê-los. Os trabalhadores migrantes indocumentados possuem os mesmos direitos trabalhistas que correspondem aos demais trabalhadores do Estado receptor, e este último deve tomar todas as medidas necessárias para que assim se reconheça e se cumpra na prática. $^{7}$

Esclareceu ainda que os Estados e os particulares não estão obrigados a estabelecerem vínculo de emprego com trabalhadores irregu-

\footnotetext{
6 Trecho Extraído do Parecer Consultivo OC-18/03 de 17 de Setembro de 2003, solicitado pelos Estados Unidos Mexicanos - A Condição Jurídica e os Direitos Dos Migrantes Indocumentados.

7 Trecho Extraído do Parecer Consultivo OC-18/03 de 17 de Setembro de 2003, solicitado pelos Estados Unidos Mexicanos - A Condição Jurídica e os Direitos Dos Migrantes Indocumentados.
} 
lares, mas caso estabeleçam, ficam obrigados a garantirem os mesmos direitos trabalhistas previstos para os trabalhadores regulares no país, na medida em que há obrigação pela nação na aplicação dos direitos empregatícios tanto no campo do direito público quanto no direito privado, caracterizando, assim, certa responsabilidade internacional por parte do Estado.

Nesse sentido:

Que os Estados têm a obrigação geral de respeitar e garantir os direitos fundamentais. Com este propósito, devem adotar medidas positivas, evitar tomar iniciativas que limitem ou violem um direito fundamental, e eliminar as medidas e práticas que restrinjam ou violem um direito fundamental.

Que o descumprimento pelo Estado, através de qualquer tratamento discriminatório, da obrigação geral de respeitar e garantir os direitos humanos, gera sua responsabilidade internacional. ${ }^{8}$

Essa responsabilidade internacional, no caso da violação dos direitos humanos, se caracteriza de diversas formas: a primeira delas decorre do Estado como empregador; a segunda praticada por um particular diante da ausência do Estado na fiscalização entre particulares; a terceira quando o migrante, empregado pelo setor público ou privado, seja privado de direitos trabalhistas previstos pelo Estado, a exemplo de aposentadoria; e quarto e último quando o empregado, no pleito de seus direitos, for privado da ampla defesa e de processo judicial.

Com isso, diante da vulnerabilidade dos migrantes em situação irregular, foram previstas várias hipóteses no sentido de assegurar a proteção dos trabalhadores indocumentados em solo estrangeiro, pois, em virtude das dificuldades de se encontrar um emprego condizente, uma vez que determinada situação propicia o pagamento de salários baixíssimos e condições precárias de trabalho, faz com que muitas empresas submetam essas migrantes em trabalhos análogas a condição de escravos, na qual, constantemente, tem-se notado na mídia, principalmente na cidade de São Paulo, a situação dos bolivianos que trabalham em condições subhumanas em troca de $\mathrm{R} \$ 0,20$ (vinte centavos) por roupas confeccionadas, de acordo com o pronunciamento da corte:

\footnotetext{
${ }^{8}$ Trecho Extraído do Parecer Consultivo OC-18/03 de 17 de Setembro de 2003, solicitado pelos Estados Unidos Mexicanos - A Condição Jurídica e os Direitos Dos Migrantes Indocumentados.
} 
Neste Parecer, a Corte se pronunciou sobre os direitos que devem ser reconhecidos e aplicados pelos Estados aos trabalhadores que, por distintas circunstâncias, emigram de seus países em procura de bem-estar econômico, e que ao não terem status migratório legal, podem ser vítimas de violações de seus direitos, entre outros, de seus direitos trabalhistas, de seus direitos à integridade, à igualdade e não discriminação. Nesse sentido, o Estado solicitante do Parecer da Corte, refere-se ao fato concreto de que, quase seis milhões de trabalhadores mexicanos vivem fora do território nacional, dos quais aproximadamente dois milhões e meio são trabalhadores migrantes indocumentados. Acrescenta que "apenas em cinco meses, (do ano de 2002), o México teve que intervir, através de suas representações consulares, em aproximadamente 383 casos em defesa dos trabalhadores mexicanos, por discriminação trabalhista, salários não pagos, indenizações por doenças adquiridas nos centros de trabalho e acidentes de trabalho, entre outros motivos. ${ }^{9}$

Assim, a corte listou, por exemplo, a proibição do trabalho forçado ou obrigatório, proibição do trabalho infantil, proteção ao trabalho feminino, com a garantia dos mesmos direitos previstos ao trabalhador masculino, como a associação sindical, duração de jornada razoável, descanso e indenização.

Com isso, nota-se que o objetivo central deste documento é demonstrar que os deslocamentos migratórios são protegidos pelo Direito Internacional dos Direitos Humanos, na qual todos os trabalhadores migrantes, inclusive os indocumentados, devem ter assegurado a proteção dos direitos humanos, a igualdade e a não discriminação:

A ideia básica de todo o documento é no sentido de que os deslocados internos não perdem os direitos que lhes são inerentes como seres humanos em razão do deslocamento, e estão protegidos pela normativa do Direito Internacional dos Direitos Humanos e do Direito Internacional Humanitário. ${ }^{10} \mathrm{Na}$ mesma linha de raciocínio, a ideia básica subjacente à Convenção Internacional sobre a Proteção dos Direitos de Todos os Trabalhadores Migrantes e dos Membros das suas Famílias (1990) é no sentido de que todos os trabalhadores qualificados como migrantes de acordo com suas disposições devem desfrutar seus direitos humanos, independentemente de sua situação jurídica; daí a posição central ocupada, também neste contexto, pelo princípio da não discriminação. ${ }^{11} \mathrm{Em}$ resumo, os trabalhadores migrantes, inclusive os indocumentados, são titulares dos direitos humanos fundamentais, que não se con-

\footnotetext{
${ }^{9}$ Trecho Extraído do Parecer Consultivo OC-18/03 de 17 de Setembro de 2003, solicitado pelos Estados Unidos Mexicanos - A Condição Jurídica e os Direitos Dos Migrantes Indocumentados.

${ }^{10}$ R. Cohen e F. Deng, Masses in Flight: The Global Crisis of Internal Displacement, Washington D.C., Brookings Institution, 1998, p. 74.

${ }^{11}$ Tal como enunciado em seu artigo 7.
} 
dicionam por sua situação jurídica (irregular ou não). Em conclusão sobre este ponto, ao princípio fundamental da igualdade e não discriminação está reservada, desde a Declaração Universal de 1948, um posicionamento verdadeiramente central no âmbito do Direito Internacional dos Direitos Humanos. ${ }^{12}$

Por fim, nota-se que os Estados estão condicionados no respeito aos direitos humanos no campo de circulação de pessoas pelo mundo, com dever de especial proteção aos migrantes indocumentados, tendo em vista que uma nação não mais pode agir, no que diz respeito ao contexto migratório, exclusivamente com base na sua pretensão nacional ou política interna.

\section{DA PROTEÇÃO DOS MIGRANTES NA ORDEM JURÍDICA BRASILEIRA}

$\mathrm{Na}$ legislação brasileira, a proteção dos direitos humanos tem previsão na Constituição da República Federativa do Brasil de 1998 que, com a redemocratização do país, consagrou em seu texto a garantia dos direitos fundamentais, assegurando, inclusive, proteção para os migrantes.

Em seu respectivo texto, o artigo $5^{\circ}$ nos revela que "Todos são iguais perante a lei, sem distinção de qualquer natureza, garantindo-se aos brasileiros e estrangeiros residentes no país a inviolabilidade do direito à vida, à liberdade, à igualdade, à segurança e à propriedade". (BRASIL, 1988).

Com efeito, nota-se que o objetivo do referido dispositivo foi o de estabelecer a igualdade de direitos entre brasileiros e estrangeiros no que diz respeito a garantia dos direitos fundamentais, uma vez que todos fazem jus aos mesmos direitos, não importando a que título o estrangeiro se encontre dentro do território brasileiro.

A despeito disso, pontua Gilmar Ferreira Mendes e Paulo Gustavo Gonet Branco (2014, p. 171-172):

$\mathrm{O}$ caput do art. $5^{\circ}$ reconhece os direitos fundamentais "aos brasileiros e aos estrangeiros residentes no País". A norma suscita a questão de saber se os estrangeiros não residentes estariam alijados da titularidade de todos os direitos fundamentais. A resposta deve ser negativa. A declaração de direitos fundamentais da Cons-

\footnotetext{
${ }^{12}$ Trecho Extraído do Parecer Consultivo OC-18/03 de 17 de Setembro de 2003, solicitado pelos Estados Unidos Mexicanos - A Condição Jurídica e os Direitos Dos Migrantes Indocumentados.
} 
tituição abrange diversos direitos que radicam diretamente no princípio da dignidade do homem - princípio que o art. $1^{\circ}$, III, da Constituição Federal toma como estruturante do Estado democrático brasileiro. O respeito devido à dignidade de todos os homens não se excepciona pelo fator meramente circunstancial da nacionalidade.

Além disso, a própria Constituição Federal de 1988 estabeleceu no mesmo artigo $5^{\circ}$, parágrafo segundo, que "Os direitos e garantias dela constantes não excluem outros direitos do regime e dos princípios por ela adotados, ou dos tratados internacionais em que a república do Brasil seja parte". (BRASIL, 1988)

Isso faz com que todos os direitos e garantias fundamentais previstos na Constituição brasileira sejam rol meramente exemplificativo, sendo admitidos todos os direitos constantes em tratados internacionais relativamente a direitos humanos do qual o Brasil tenha ratificado, tornando-se automaticamente executáveis no país em face de qualquer estrangeiro, seja residente ou não.

Esses tratados internacionais incorporados pelo ordenamento jurídico brasileiro conferem aos nacionais e estrangeiros o direito de reclamar tanto no plano interno, quanto internacionalmente, a proteção dos direitos fundamentais, tendo em vista que a recepção desses tratados pela Constituição torna o Brasil obrigado ao cumprimento dos direitos humanos, de acordo com o Direito Internacional.

Ressalta-se que, nos termos do art. $5^{\circ}$, os migrantes no país, assim como os nacionais, têm consagrados na constituição o direito à vida, igualdade, legalidade, devido processo legal, motivação dos atos administrativos e judiciais, direito de petição, juiz natural, direito à livre manifestação de pensamento, direito à associação, direito de locomoção, intimidade e vida privada e direito de propriedade.

Outro ponto de destaque da proteção interna do estrangeiro diz respeito a nova Lei de Migrações, cujo projeto de Lei no Senado $n^{\circ}$ 288/2013, substitui o atual Estatuto do Estrangeiro de 1980, estabelecendo garantias para tratamento igualitário dos estrangeiros que ingressam no país.

Além dos princípios acima mencionados constantes no art. $5^{\circ}$ da Constituição Federal de 1998, a nova Lei de Migrações traz em seus artigos $3^{\circ}$ e $4^{\circ}$ princípios e garantias que asseguram ao migrante tratamento igualitário em relação aos nacionais. 
Em seu art. $3^{\circ}$, a nova Lei de Migrações estabelece que a política migratória brasileira deverá reger-se por todos os princípios ali constantes, merecendo destaque o princípio do repúdio e prevenção à xenofobia, ao racismo e a quaisquer formas de discriminações; o princípio da não criminalização da imigração; princípio da acolhida humanitária; princípio da igualdade de tratamento e de oportunidade ao migrante e seus familiares; princípio da proteção integral e atenção ao superior interesse da criança e do adolescente migrante e o princípio da promoção do reconhecimento acadêmico e do exercício profissional no Brasil.

Vale destacar que, em se tratando do superior interesse da criança no âmbito da migração, o Parecer Consultivo OC 21 de 19 de agosto de 2014 solicitado à Corte Interamericana de Direito Humanos pelo Brasil, Paraguai, Uruguai e Argentina, buscou estabelecer direitos e garantias para as crianças no contexto da migração ou em necessidade de proteção internacional, salientando, especialmente, sobre as garantias do devido processo legal, da não privação de liberdade de crianças e do princípio da não devolução (non-refoulement), da qual o nova lei de migração incorpora em sua legislação, merecendo análise abaixo.

\section{DAS GARANTIAS DO DEVIDO PROCESSO NO ÂMBITO MIGRATÓRIO}

A Corte Interamericana, no referido parecer consultivo, tratou das garantias do devido processo legal nas questões migratórias envolvendo crianças, uma vez que deve ser garantido o direito e condições de se defender adequadamente diante de qualquer ato do Estado ou qualquer autoridade pública, administrativa, legislativa ou judicial, prevalecendo noção de justiça:

Corte já indicou que o direito ao devido processo se refere ao conjunto de requisitos que devem ser observados nas instâncias processuais para que as pessoas estejam em condições de defender adequadamente seus direitos diante de qualquer ato do Estado, adotado por qualquer autoridade pública, seja administrativa, legislativa ou judicial, que possa afetá-los. ${ }^{13} \mathrm{O}$ devido processo, por

\footnotetext{
${ }^{13}$ Cf. Garantias Judiciais em Estados de Emergência (arts. 27.2, 25 e 8 Convenção Americana sobre Direitos Humanos), supra, par. 27; Caso do Tribunal Constitucional Vs. Peru. Mérito, Reparações e Custas. Sentença de 31 de janeiro de 2001. Série C No 71, par. 69, e Caso Família Pacheco Tineo Vs. Bolívia, par. 130.
} 
sua vez, encontra-se intimamente ligado à noção de justiça, ${ }^{14}$ que se reflete em: (i) um acesso à justiça não apenas formal, mas que reconheça e resolva os fatores de desigualdade real dos processados, (ii) o desenvolvimento de um julgamento justo e (iii) a resolução das controvérsias de forma tal que a decisão adotada se aproxime do maior nível de correção do direito, isto é, que se assegure, na maior medida possível, sua solução justa. ${ }^{15}$

As garantias do devido processo legal são aplicáveis a qualquer pessoa independentemente de sua idade ou nacionalidade. Já é um direito imanente ao status migratório, uma vez que o Estado deve garantir a todo estrangeiro, ainda que em situação irregular, a possibilidade de se fazer valer tais atributos:

Outrossim, as garantias do devido processo são aplicadas a qualquer pessoa independentemente de sua idade e condição de estadia em um país. Nessa perspectiva, a Corte esclareceu que o devido processo legal é um direito que deve ser garantido a toda pessoa, independentemente de seu status migratório. ${ }^{16}$ Isso significa que o Estado deve garantir que toda pessoa estrangeira, mesmo quando for um migrante em situação irregular, tenha a possibilidade de fazer valer seus direitos e defender seus interesses de forma efetiva e em condições de igualdade processual com outros jurisdicionados. ${ }^{17}$

Nota-se que as aludidas garantias devem ser respeitadas independentemente das pessoas às quais se refiram, observando que, ao tratarse de criança, o Estado deverá conferir a elas especial atenção, tendo em vista que o reconhecimento do processo migratório em relação a pessoas adultas não se faz nas mesmas condições de igualdade.

Assim, a própria Corte Interamericana confere às crianças várias garantias especiais no processo migratório, considerando critérios de maior primazia:

"Tendo as anteriores considerações como base, a Corte se referirá a seguir às garantias que, conforme o Direito Internacional dos Direitos Humanos, devem reger todo processo migratório que envolva crianças, fazendo menção especial, quando corresponda, àquelas que exigem mais relevância neste tipo de processo. Em consequência, a Corte se referirá aos seguintes aspectos: (i) o di-

\footnotetext{
${ }^{14}$ Cf. O Direito à Informação sobre a Assistência Consular no Marco das Garantias do Devido Processo Legal, par. 117

${ }^{15}$ Parecer Consultivo OC-21/14 de 19 de Agosto de 2014 cit., p. 42.

${ }^{16}$ Cf. Condição Jurídica e Direitos dos Migrantes Indocumentados, pars. 121 e 122, e Caso Vélez Loor Vs. Panamá, par. 143.

${ }^{17}$ Cf. Caso Vélez Loor Vs. Panamá, par. 143.
} 
reito de ser notificado da existência de um procedimento e da decisão que se adote no âmbito do processo migratório; (ii) o direito a que os processos migratórios sejam conduzidos por um funcionário ou juiz especializado; (iii) o direito da criança a ser ouvida e a participar nas diferentes etapas processuais; (iv) o direito a ser assistido gratuitamente por um tradutor e/ou intérprete; (v) o acesso efetivo à comunicação e assistência consular; (vi) o direito a ser assistido por um representante legal e a comunicar-se livremente com este representante; (vii) o dever de designar um tutor no caso de criança desacompanhada ou separada; (viii) o direito a que a decisão adotada avalie o interesse superior da criança e seja devidamente fundamentada; (ix) o direito a recorrer da decisão perante um juiz ou tribunal superior com efeitos suspensivos; e (x) o prazo razoável de duração do processo". ${ }^{18}$

Com isso, exemplificando, o Tribunal reconhece que a falta de notificação ao migrante sobre a existência de um processo acarreta violação ao direito de defesa, que também é estendido às crianças migrantes. Logicamente que, nesse caso, há pessoal especializado para se comunicar com elas e tratar do assunto tanto administrativamente, quanto judicial.

Além disso, todo processo migratório deve ser conduzido por um funcionário ou juiz especializado no assunto, garantida a sua imparcialidade e respeito à legislação pertinente.

Importante ressaltar também que, no caso de migrantes menores de idade, as decisões em matéria migratória não poderão ser delegadas a funcionários não especializados, pois os Estados devem garantir que tais decisões sejam feitas por pessoas capacitadas, de forma a identificar as necessidades especiais e de proteção às crianças migrantes.

O menor também precisa ser ouvido nas diversas etapas do processo, pois com isso busca-se o seu melhor interesse. O Estado, no caso das crianças migrantes que não entendam o idioma, deve garantir que elas sejam assistidas por um tradutor e/ou intérprete, sempre com o objetivo de que seus interesses superiores sejam considerados.

A Corte menciona ainda que o funcionário consular tem o dever de zelar primordialmente pelos interesses dos menores, tendo em vista que as decisões administrativas ou judiciais que sejam adotadas no país receptor devem ser avaliadas de acordo com seu interesse superior, na medida em que sua situação de vulnerabilidade, em razão de se encontrarem fora de seu país de origem, desacompanhadas ou separadas de sua família, merece especial atenção por parte das nações.

\footnotetext{
${ }^{18}$ Parecer Consultivo OC-21/14 de 19 de Agosto de 2014 cit.,p. 44.
} 
O Tribunal destaca também que os Estados têm o dever de garantir a toda criança no contexto migratório representação jurídica especializada por meio de serviços estatais gratuitos, respeitando-se o efetivo acesso à justiça.

No caso de menores desacompanhados ou separados de suas famílias, o Estado tem a obrigação de designar um tutor até que eles atinjam a maioridade, o que ocorre aos 18 (dezoito) anos de idade, podendo, logo após a emancipação, abandonar o território ou a jurisdição daquela nação, devendo, referido tutor, no exercício de sua tutela, conhecer evidentemente os interesses do menor, atendendo-se sempre às necessidades sociais, educativa, jurídica e psicológicas daquele (a) migrante.

Para as decisões emanadas no âmbito migratório, a Corte menciona que todas elas deverão ser fundamentadas de acordo com a administração da justiça, garantindo-se sempre o direito das pessoas de não serem julgadas de forma arbitrária numa sociedade democrática.

Em se tratando de decisão, caberá a toda pessoa no contexto migratório o direito de recorrer, com efeito suspensivo, seja no âmbito administrativo ou judicial, de deliberação pela deportação ou expulsão de um país. No caso da criança, esse recurso merece destaque, pois será ele utilizado caso o interesse superior do menor não seja atendido, ou seja, quando de fato não foi ela devidamente ouvida ou suas opiniões não terem sido devidamente consideradas, lembrando que todo o trâmite processual deverá respeitar a duração razoável do processo, em respeito à celeridade processual.

\section{DO PRINCÍPIO DA NÃO PRIVAÇÃO DE LIBERDADE DE CRIANÇAS E DO PRINCÍPIO DE NÃO DEVOLUÇÃO (NON-REFOULEMENT)}

Outro ponto importante a ser destacado refere-se ao Princípio da Não Privação de Liberdade de Crianças por sua situação migratória irregular.

Mais especificamente, o Alto Comissariado das Nações Unidas para os Refugiados entendeu, em relação às pessoas em busca de proteção internacional, que a detenção equivale à "privação da liberdade ou confinamento em um local fechado, do qual não se permite que o solicitante de refúgio saia pela própria vontade, incluindo, mas não limitado a presídios ou centros de detenção, ins- 
talações de recepção ou retenção". ${ }^{19}$ Além disso, entende que "[a]s distinções entre a privação da liberdade e restrições menores à circulação são de 'maior ou menor grau de intensidade e não de natureza ou substância". ${ }^{20}$ Por conseguinte, "[qualquer que seja o nome dado ao local específico da detenção, as questões mais importantes dizem respeito a se o solicitante de refúgio está sendo privado de sua liberdade de fato e se esta privação é considerada legal de acordo com o Direito Internacional". ${ }^{21}$ Outorga-se assim, portanto, uma precisão adicional ao conceito de privação de liberdade em hipóteses em que se restringe a liberdade de ir e vir, mas que esta restrição gera, na situação concreta, uma afetação de tal envergadura nos direitos da pessoa, como no direito de solicitar e receber asilo, que esta restrição resulta comparável a uma medida privativa de liberdade em razão do "tipo, duração, efeitos e forma de implementação. ${ }^{22}$

\section{A Corte entende que o princípio de ultima ratio de detenção só deve ser aplicado em último caso como caráter pedagógico do processo penal.}

Com efeito, constitui um princípio do Direito Internacional dos Direitos Humanos, ${ }^{23}$ cristalizado na Convenção sobre os Direitos da Criança ${ }^{24}$ e desenvolvido pela jurisprudência desta Corte no marco do direito à liberdade pessoal em casos relativos a jovens

\footnotetext{
${ }^{19}$ Alto Comissariado das Nações Unidas para os Refugiados (ACNUR), Diretrizes sobre os critérios aplicáveis e os padrões relativos à detenção de solicitantes de refúgio, e soluções alternativas à detenção, publicadas em 2012, introdução, par. 5.

${ }^{20}$ Alto Comissariado das Nações Unidas para os Refugiados (ACNUR), Diretrizes sobre os critérios aplicáveis e os padrões relativos à detenção de solicitantes de refúgio, e soluções alternativas à detenção, publicadas em 2012, introdução, par. 6.

${ }^{21}$ Alto Comissariado das Nações Unidas para os Refugiados (ACNUR), Diretrizes sobre os critérios aplicáveis e os padrões relativos à detenção de solicitantes de refúgio, e soluções alternativas à detenção, publicadas em 2012, introdução, par. 7, citando TEDH, Caso Guzzardi Vs. Itália, No 7367/76. Sentença de 6 de novembro de 1980, par. 93.

${ }^{22}$ TEDH, Caso Amuur Vs. França, $N^{\circ}$ 19776/92. Sentença de 25 de junho de 1996, par. 42 (tradução da Secretaria da Corte).

${ }^{23}$ Ver a regra 13.1 das Regras mínimas padrão das nações unidas para a administração da justiça da criança e do adolescente (Regras de Beijing), UN Doc. A/RES/40/33, adotadas em 29 de novembro de 1985; a regra 6.1 das Regras mínimas padrão das Nações Unidas para a elaboração de medidas não privativas de liberdade (Regras de Tóquio), UN. Doc. A/RES/45/110, adotadas em 14 de dezembro de 1990; a regra 17 das Regras das Nações Unidas para a proteção dos menores privados de liberdade (Regras de Havana), UN Doc. A/RES/45/113, adotadas em 14 de dezembro de 1990, e o princípio III dos Princípios e Boas Práticas sobre a Proteção das Pessoas Privadas da Liberdade nas Américas da Comissão Interamericana de Direitos Humanos, adotados durante o $131^{\circ}$ Período Ordinário de Sessões, celebrado de 3 a 14 de março de 2008.

${ }^{24} \mathrm{O}$ artigo 37.b) da Convenção sobre os Direitos da Criança dispõe que os Estados Partes zelarão para que: nenhuma criança seja privada de sua liberdade de forma ilegal ou arbitrária. A detenção, a reclusão ou a prisão de uma criança será efetuada em conformidade com a lei e apenas como último recurso e durante o mais breve período de tempo que for apropriado.
} 
em conflito com a lei penal, ${ }^{25}$ que a privação de liberdade, seja em sua faceta cautelar ou como sanção penal, constitui uma medida de último recurso que deve ser aplicada, quando proceda, pelo menor tempo possível, ${ }^{26}$ dado o objetivo fundamentalmente pedagógico do processo penal relativo a pessoas menores de idade. ${ }^{27} \mathrm{E}$ assim que a privação de liberdade no contexto da justiça penal juvenil deve respeitar os princípios de legalidade, excepcionalidade e máxima brevidade. ${ }^{28}$ Além disso, a excepcionalidade da prisão preventiva opera com maior rigorosidade, já que a regra deve ser a liberdade e, caso se verifique a necessidade de cautela, deve primar a aplicação de medidas substitutivas. ${ }^{29}$

De acordo com o Direito Internacional dos Direitos Humanos, a Corte considera que a privação de liberdade das crianças desacompanhadas ou separadas de sua família é totalmente descabida, tendo em vista que o Estado, conforme o Comitê dos Direitos da Criança, está obrigado a garantir uma proteção especial a elas e buscar atingir, na melhor medida, seu interesse superior:

Em aplicação do artigo 37 da Convenção e do princípio do interesse superior do menor, não se deve privar de liberdade, como regra geral, os menores desacompanhados ou separados de sua família. A privação de liberdade não poderá ser justificada apenas porque o menor esteja sozinho ou separado de sua família, nem por sua condição de imigrante ou residente. [...] Por conseguinte, dever ser feito todo o possível, inclusive acelerar os processos pertinentes, com o objetivo de que os menores desacompanhados ou separados de sua família sejam postos em liberdade e colocados em outras instituições de alojamento. ${ }^{30}$

No caso das crianças migrantes, a Corte ainda ressalta que:

\footnotetext{
${ }^{25}$ Cf. Caso "Instituto de Reeducação do Menor" Vs. Paraguai, supra, pars. 230 e 231, e Caso Mendoza e outros Vs. Argentina, par. 162.

${ }^{26}$ Cf. Comitê dos Direitos da Criança, Observação Geral No 10: Os Direitos da Criança no âmbito da justiça de menores, UN Doc. CRC/C/GC/10, 25 de abril de 2007, pars. 70, 79 e 80. Ver, também, Comitê dos Direitos da Criança, Observação Geral No 6: Tratamento dos menores desacompanhados e separados de sua família fora de seu país de origem, par. 61.

${ }^{27}$ Cf. Comitê dos Direitos da Criança, Observação Geral No 10: Os Direitos da Criança no âmbito da justiça de menores, par. 51.

${ }^{28}$ Ver artigo 37.b) e d) da Convenção sobre os Direitos da Criança.

${ }^{29}$ Parecer Consultivo OC-21/14 de 19 de Agosto de 2014 cit.,p. 54-55.

${ }^{30}$ Comitê dos Direitos da Criança, Observação Geral No 6: Tratamento dos menores desacompanhados e separados de sua família fora de seu país de origem, supra, par. 61. Ver, também, Relatório apresentado pela Relatora Especial, Sra. Gabriela Rodríguez Pizarro, Grupos específicos e indivíduos: Trabalhadores migrantes, de acordo com a resolução 2002/62 da Comissão de Direitos Humanos, UN Doc. E/CN.4/2003/85, 30 de dezembro de 2002, par. 75.a).
} 
Em suma, a Corte entende que as crianças migrantes e, em particular aqueles em situação migratória irregular que se encontram em uma situação de maior vulnerabilidade, requerem do Estado receptor uma atuação especificamente orientada à proteção prioritária de seus direitos, que deve ser definida segundo as circunstâncias particulares de cada caso concreto, isto é, se se encontram com sua família, separados ou desacompanhados, e atendendo o seu interesse superior. Para tanto, os Estados, em cumprimento de suas obrigações internacionais na matéria, devem elaborar e incorporar em seu ordenamento interno um conjunto de medidas não privativas de liberdade a serem ordenadas e aplicadas enquanto se desenvolvem os processos migratórios visando, de forma prioritária, à proteção integral dos direitos da criança, de acordo com as características descritas, com estrito respeito de seus direitos humanos e ao princípio de legalidade. ${ }^{31}$

Isso se aplica também na questão dos alojamentos para crianças acompanhadas ou separadas de suas famílias, onde o Estado tem o dever de assegurar espaços de alojamento com infraestrutura adequada, regime adequado que assegure a proteção de seus direitos, bem como assistência médica, jurídica, apoio educativo e atenção integral, especialmente aquelas portadoras de deficiência física ou de doenças como o HIV/AIDS, inclusive com pessoal especializado na psicologia infantil.

E, por fim, em se tratando do Princípio de Não Devolução (Non-Refoulement), tem se entendido que uma das obrigações internacionais associadas a esse princípio é o da prevenção de tortura, o que faz com que o Estado respeite normas de direitos humanos e não deporte ou extradite uma pessoa sujeita a jurisdição de outro país, com fundado receio de perigo a sua integridade:

Assim, a partir do artigo $5^{\circ}$ da Convenção Americana, lido em conjunto com as obrigações erga omnes de respeitar e fazer respeitar as normas de proteção dos direitos humanos, decorre o dever do Estado de não deportar, devolver, expulsar, extraditar ou remover de outro modo uma pessoa que esteja sujeita à sua jurisdição para outro Estado, ou para um terceiro Estado que não seja seguro, quando exista presunção fundada para crer que estaria em perigo de ser submetida a tortura, tratamentos cruéis, desumanos ou degradantes. ${ }^{32}$

\footnotetext{
${ }^{31}$ Parecer Consultivo OC-21/14 de 19 de Agosto de 2014 cit.,p. 62.

${ }^{32}$ De igual forma, o artigo 7 do Pacto Internacional sobre Direitos Civis e Políticos estabelece: “[n]inguém poderá ser submetido à tortura, nem a penas ou tratamento cruéis, desumanos ou degradantes. Será proibido sobretudo, submeter uma pessoa, sem seu livre consentimento, a experiências médias ou cientificas". Pacto Internacional sobre Direitos Civis e Políticos, adotado em 16 de dezembro 1966, entrada em vigor em 23 de março de 1976. Os seguintes 31 Estados Membros da OEA são parte deste tratado: Argentina, Bahamas, Barbados, Belize, Bolívia, Brasil, Canadá, Chile, Colômbia,
} 
Neste sentido, percebe-se como os Pareces Consultivos possuem papel central na garantia dos direitos humanos dentro da política migratória.

\section{CONCLUSÃO}

A pesquisa possuía como tema central verificar quais são os direitos humanos aplicados na migração, em especial no que tange ao entendimento dos Pareces Consultivos elaborados pela Corte Interamericana de Direitos Humanos sobre o tema.

Ao final da exposição, percebeu-se que os Pareces Consultivos elaborados pela Comissão Interamericana são marco de reconhecimento dos direitos humanos dos imigrantes.

Neste sentido, o tema central do presente trabalho, ainda negligenciado pela comunidade científica, representa o início de um debate na

Costa Rica, Dominica, Equador, El Salvador, Estados Unidos da América, Granada, Guatemala, Guyana, Haiti, Honduras, Jamaica, México, Nicarágua, Panamá, Paraguai, Peru, República Dominicana, San Vicente e Granadinas, Suriname, Trinidad e Tobago, Uruguai e Venezuela. O Comitê de Direitos Humanos das Nações Unidas interpretou essa norma no sentido de incluir um dever dos Estados Partes de "não [...] expor as pessoas ao perigo de serem submetidas a torturas ou a penas ou tratamentos cruéis, desumanos ou degradantes ao regressar a outro país como resultado de extradição, expulsão ou devolução". Comitê de Direitos Humanos, Observação Geral N 20, Substitui a Observação Geral $N^{\circ}$ 7. Proibição da tortura e dos tratamentos ou penas cruéis (Artigo 7), UN Doc. HRI/GEN/1/Rev.7, 10 de março de 1992, par. 9. Este dever surge das obrigações gerais do artigo 2 do Pacto, que exige que os Estados Partes respeitem e garantam os direitos do Pacto a todos os indivíduos que se encontrem em seu território e a todas as pessoas sujeitas à sua jurisdição, o que implica "[n]a obrigação de não extraditar, deportar, expulsar ou retirar de outro modo uma pessoa de seu território, quando há razões de peso para acreditar que existe um risco real de provocar um dano irreparável, como o contemplado pelos artigos 6 [direito à vida] e 7 [proibição de tortura e outros tratamentos cruéis, desumanos ou degradantes] do Pacto, no país para onde se realizará essa saída forçada ou em qualquer país para o qual a pessoa seja expulsa posteriormente". Comitê de Direitos Humanos, Observação Geral $N^{\circ}$ 31, A natureza da obrigação jurídica geral imposta, UN Doc. CCPR/C/21/Rev.1/Add.13, 26 de maio de 2004, par. 12. Além disso, em várias decisões sobre casos individuais, o Comitê afirmou que não é possível extraditar, deportar, expulsar ou remover de nenhuma maneira uma pessoa do território de um Estado se existem motivos suficientes para acreditar que existe risco de dano irreparável contra seus direitos, e sem antes tomar em consideração as alegações da pessoa sobre o risco existente. Comitê de Direitos Humanos, Comitê de Direitos Humanos, Joseph Kindler c. Canadá (Comunicação N 470/1991), UN Doc. CCPR/C/48/D/470/1991, parecer adotado em 11 de novembro de 1993, par. 6.2; Charles Chitat $\mathrm{Ng}$ c. Canadá (Comunicação $\mathrm{N}^{\circ}$ 469/991), UN Doc. CCPR/C/49/D/469/1991, parecer adotado em 7 de janeiro de 1994, par. 6.2; Jonny Rubin Byahuranga c. Dinamarca (Comunicação $\mathrm{N}^{\circ}$ 1222/2003), UN Doc. CCPR/C/82/D/1222/2003, parecer adotado em 9 de dezembro 2004, par. 11.3, e Jama Warsame c. Canadá, (Comunicação No 1959/2010), UN Doc. CCPR/C/102/D/1959/2010, parecer adotado em 1 de setembro 2011, par. 8.3. 
exata medida em que reconhece formalmente a condição especialíssima dos migrantes, especialmente na proteção de direitos humanos no âmbito migratório e na atual problemática de direito internacional.

Assim, tem-se que os Estados estão condicionados no respeito aos direitos humanos no campo de circulação de pessoas pelo mundo, tendo em vista que uma nação não mais pode agir, no que diz respeito ao contexto migratório, exclusivamente com base na sua pretensão nacional ou política interna.

\section{REFERÊNCIAS}

BRASIL. Constituição da República Federativa do Brasil de 1988. Brasília, DF: Senado Federal, São Paulo: Saraiva, 2015.

FARENA, Maritza Natalia Ferretti Cisneros, Direitos humanos dos migrantes: ordem jurídica internacional e brasileira, 1. Ed., Curitiba: Juruá, 2012.

MENDES, Gilmar Ferreira; BRANCO, Paulo Gustavo Gonet, Curso de direito constitucional, 9. ed. rev. e atual., São Paulo: Saraiva, 2014.

RAMOS, André de Carvalho, Direitos humanos em juízo, São Paulo: Max Limonad, 2001.

SOARES, Guido Fernando Silva, Raízes históricas das normas internas de proteção aos estrangeiros - Os direitos humanos e a proteção dos estrangeiros, Revista de Informação Legislativa, Brasília: Senado Federal, Subsecretaria de Edições Técnicas, a. 41, n. 162, abr./jun. 2004, (Edição especial comemorativa dos 40 anos).

TRINDADE, Antonio Augusto Cançado, A proteção internacional dos direitos humanos. Fundamentos jurídicos e instrumentos básicos, São Paulo: Saraiva, 1991.

TRINDADE, Antonio Augusto Cançado, Elementos para un Enfoque de Derechos Humanos del Fenómeno de los Flujos Migratorios Forzados, Cidade da Guatemala, OIM/IIDH (Cadernos de Trabalho sobre Migração ${ }^{\circ}$ 5), 2001.

VEDOVATO, Luís Renato, Direito de ingresso do estrangeiro: a circulação das pessoas pelo mundo no cenário globalizado, Livro digital, São Paulo: Atlas, 2013. 